УДК 636.2.034

(C) 2013

Вацький В. Ф., кандидат сільськогосподарських наук,

Величко С. А., аспірант *

Полтавська державна аграрна академія

\title{
ПОКАЗНИКИ РАННЬОГО ОНТОГЕНЕЗУ МОЛОЧНОЇ ХУДОБИ І МОЖЛИВОСТІ ЇХ ВИКОРИСТАННЯ ДЛЯ ПІДВИЩЕННЯ ПРОДУКТИВНОСТІ МОЛОЧНИХ СТАД
}

\section{Рецензент - кандидат сільськогосподарських наук О. О. Дерэсговський}

\begin{abstract}
Вивчено особливості зв 'язку показників ембріонального розвитку телят із рівнем їх наступної молочної продуктивності як корів-первісток. Встановлено, щуо більш продуктивні корови характеризуються меншою масою при народженні, але різниия недостовірна. Коротка і середня тривалість ембріонального розвитку сприяє прояву високої молочної продуктивності. Використання показників ембріональної швидкості росту й відношення маси теляти при народженні до маси матері поряд із показниками тривалості ембріонального розвитку і маси при народженні при оцуіниі індивідуальних особливостей організму - дає можливість виявити більш продуктивних корів одразу ж після їх народження.
\end{abstract}

Ключові слова: тривалість ембріогенезу, ембріональна швидкість росту, маса при народженні, молочна продуктивність.

Постановка проблеми. Проблема вирощування високопродуктивних тварин і підвищення продуктивності молочної худоби має неабияке практичне значення. Вирішити ії можна завдяки знанням закономірностей індивідуального розвитку тварин і факторів, що обумовлюють цей процес. Володіння такого роду знаннями дасть змогу керувати розвитком організму тварин у необхідному для людини напрямі. Цілеспрямовано впливаючи тим чи іншим чином на однакових за якістю телят, можна виростити зовсім різних за продуктивністю корів. Для раціонального використання засобів вирощування важливо знати потенційні можливості організму кожної тварини, починаючи 3 iï народження. Проблемі зв'язку показників раннього онтогенезу з ростом, розвитком і продуктивністю тварин присвячено обширний науковий матеріал, але у зв'язку зі складністю використання існуючих даних у практичних цілях дослідження в цьому напрямі доцільно продовжити.
Аналіз основних досліджень і публікацій, у яких започатковано розв'язання проблеми. Основною господарсько корисною ознакою сільськогосподарських тварин $є$ їх продуктивність, ступінь прояву якої залежить від реалізації спадкових задатків продуктивності в онтогенезі.

У процесі індивідуального розвитку тварин, починаючи 3 моменту утворення зиготи і закінчуючи природною смертю організму, під впливом умов вирощування, утримання та використання відбувається постійна реалізація спадкової інформації, а ступінь іiі реалізації на певному етапі онтогенезу залежить від уже реалізованої програми розвитку на попередньому етапі [1].

3 метою оцінки потенційних можливостей організму тварин, отримання від них у майбутньому максимальної продуктивності та підвищення ефективності їх утримання вчені відмічають важливість визначення індивідуальних особливостей організму тварин у ранньому віці [8]. Показником сформованості та індикатором життєвої сили телят на початку постембріонального розвитку є їх маса при народженні.

Існує досить обгрунтована думка [2, 3, 9] про існування позитивного зв'язку маси телят при народженні 3 майбутнім рівнем їх молочної продуктивності. Однак, Н. Е. Чернякова (1975) та інші автори повідомляють, що маса телят при народженні суттєво не впливає на величину майбутніх надоїв і не може бути використана для прогнозування продуктивності у ранньому віці [10]. Legault C. R. (1962) вважає, що маса телят при народженні й рівень їх майбутньої продуктивності є генетично незалежними факторами [11]. Подоба Е. Г. (1956) відмічає, що маса телят при народженні може вважатися показником якості тварин лише 3 тієї причини, що 3 цим показником до певної міри пов'язана їх енергія росту в ембріональний період, яка зберігається

\footnotetext{
* Науковий керівник - кандидат сільськогосподарських наук В. Ф. Ваџький
} 
й після народження телят. Він вважає, що тривалість ембріонального розвитку теляти (поряд із масою при народженні) $є$ певним показником повноцінності його розвитку в ембріональний період, а відповідно, до певної міри, показником життєвості, довговічності, інтенсивності обміну речовин, тобто тих властивостей організму, які визначають майбутню продуктивність тварин.

Важливим показником, що впливає на масу телят при народженні, є жива маса матері [5]. Подоба Е. Г. (1958) виявив, що відношення маси теляти при народженні до маси матері набагато тісніше пов'язане $з$ тривалістю ембріонального розвитку, ніж просто маса при народженні, а відношення маси теляти при народженні до маси матері у зв'язку 3 тривалістю ембріонального розвитку є більш точним показником повноцінності його розвитку в утробі матері, ніж маса при народженні.

Мета і завдання досліджень. Метою досліджень було прослідкувати відмінності рівня молочної продуктивності корів, які характеризуються різними показниками розвитку в ембріональний період. Завданням досліджень було встановити закономірності зв'язку показників раннього онтогенезу молочної худоби з рівнем іiі молочної продуктивності в майбутньому.

Матеріал і методи досліджень. Дослідження проведені на поголів'ї корів української червоно-рябої молочної породи СВК «Батьківщина»

Котелевського району Полтавської області. На основі даних маси корів при народженні, тривалості їх ембріонального розвитку, надою та вмісту жиру в молоці за першу лактацію, а також маси їх матерів після отелення було сформовано базу даних по 355 коровах.

Визначали швидкість росту в ембріональний період та відношення маси телят при народженні до маси корів-матерів при отеленні. Оцінку рівня молочної продуктивності проводили з урахуванням вмісту жиру в молоці шляхом визначення кількості молока за 305 днів першої лактації 3 вмістом молочного жиру $4 \%$.

Біометричну обробку одержаних даних проводили згідно з методикою Є. К. Меркур'євої [4] на ПЕОМ із використанням програмного забезпечення Microsoft Excel 2007.

Результати досліджень. Вчені давно дійшли згоди щодо важливості оцінки спадкових задатків продуктивності молочної худоби в ранньому віці. 3 цією метою використовують показники тривалості ембріонального розвитку, ембріональної швидкості росту, маси при народженні, відношення маси теляти при народженні до маси матері. Закономірності зв'язку між цими показниками краще простежуються на основі розподілу всіх тварин $(\mathrm{M}= \pm 0,5 \sigma)$ на групи з більшими $(\mathrm{M}+)$, середніми $\left(\mathrm{M}_{0}\right)$ та меншими $(\mathrm{M}-)$ їх величинами (табл. 1).

\section{1. Зв'язок між показниками раннього онтогенезу}

\begin{tabular}{|c|c|c|c|c|c|}
\hline & $\mathrm{n}$ & $\begin{array}{c}\text { Тривалість } \\
\text { ембріонального } \\
\text { розвитку, днів }\end{array}$ & $\begin{array}{c}\text { Ембріональна } \\
\text { швидкість } \\
\text { росту, г }\end{array}$ & $\begin{array}{c}\text { Маса при } \\
\text { народженні, } \\
\text { кг } \\
\end{array}$ & $\begin{array}{c}\text { Маса телят } \\
\text { при народженні } \\
\text { / маса матері, \% } \\
\end{array}$ \\
\hline & & $\mathrm{M} \pm \mathrm{m}$ & $\mathrm{M} \pm \mathrm{m}$ & $\mathrm{M} \pm \mathrm{m}$ & $\mathrm{M} \pm \mathrm{m}$ \\
\hline \multicolumn{6}{|c|}{ За тривалістю ембріонального розвитку } \\
\hline Тривалий $(\mathrm{M}+)$ & 108 & $287,3 \pm 0,32$ & $106,6 \pm 0,86$ & $30,6 \pm 0,24$ & $5,8 \pm 0,07$ \\
\hline Середній $\left(\mathrm{M}_{0}\right)$ & 148 & $280,3 \pm 0,14$ & $109,6 \pm 0,80$ & $30,7 \pm 0,22$ & $5,7 \pm 0,06$ \\
\hline Короткий (М-) & 99 & $274,2 \pm 0,28$ & $110,5 \pm 0,74$ & $30,3 \pm 0,20$ & $5,6 \pm 0,05$ \\
\hline \multicolumn{6}{|c|}{ За ембріональною швидкістю росту } \\
\hline Швидкоростучі (M+) & 92 & $278,9 \pm 0,55$ & $120,2 \pm 0,71$ & $33,5 \pm 0,22$ & $6,3 \pm 0,07$ \\
\hline Середньоростучі $\left(\mathrm{M}_{0}\right)$ & 159 & $280,7 \pm 0,45$ & $108,5 \pm 0,19$ & $30,5 \pm 0,06$ & $5,7 \pm 0,04$ \\
\hline Повільноростучі (М-) & 104 & $282,3 \pm 0,55$ & $99,7 \pm 0,50$ & $28,1 \pm 0,15$ & $5,3 \pm 0,05$ \\
\hline \multicolumn{6}{|c|}{ За масою при народженні } \\
\hline Важкі (M+) & 102 & $280,9 \pm 0,59$ & $119,1 \pm 0,72$ & $33,4 \pm 0,20$ & $6,3 \pm 0,07$ \\
\hline Середні $\left(\mathrm{M}_{0}\right)$ & 145 & $280,6 \pm 0,46$ & $108,4 \pm 0,23$ & $30,4 \pm 0,04$ & $5,7 \pm 0,04$ \\
\hline Легкі (M-) & 108 & $280,6 \pm 0,54$ & $100,1 \pm 0,51$ & $28,1 \pm 0,14$ & $5,3 \pm 0,04$ \\
\hline \multicolumn{6}{|c|}{ За співвідношенням маси телят при народженні до маси матерів } \\
\hline Великі (M+) & 101 & $281,5 \pm 0,54$ & $116,4 \pm 0,92$ & $32,8 \pm 0,25$ & $6,5 \pm 0,05$ \\
\hline Середні $\left(\mathrm{M}_{0}\right)$ & 138 & $280,2 \pm 0,50$ & $107,7 \pm 0,49$ & $30,2 \pm 0,13$ & $5,7 \pm 0,02$ \\
\hline Дрібні (М-) & 116 & $280,7 \pm 0,51$ & $103,9 \pm 0,70$ & $29,1 \pm 0,19$ & $5,0 \pm 0,03$ \\
\hline У середньому & 355 & $280,7 \pm 0,30$ & $108,9 \pm 0,48$ & $30,6 \pm 0,13$ & $5,7 \pm 0,04$ \\
\hline
\end{tabular}


Дані таблиці 1 свідчать про існування позитивного зв'язку між показниками маси при народженні, ембріональної швидкості росту та відношення маси теляти при народженні до маси матері. Простежується слабкий зв'язок цих показників із тривалістю ембріонального розвитку. Виявлена Е. Г. Подобою (1958) закономірність, що відношення маси теляти при народженні до маси матері тісніше пов'язане з тривалістю ембріонального розвитку, ніж просто маса при народженні, має місце і в даному дослідженні.

Важливою умовою оцінки індивідуальних особливостей організму тварин на початку постембріонального розвитку є комплексний підхід. Чим більше показників індивідуального розвитку тварин буде враховано при цьому, тим точнішою буде оцінка їх продуктивних можливостей. Відомо, що телята, які характеризуються однаковою величиною одного показника їх розвитку, відрізняються за величиною іншого. Так, телята 3 однаковою масою при народженні можуть бути отримані від корів-матерів із різною живою масою. В більшості випадків вони відрізняються за тривалістю ембріонального розвитку та швидкі- стю росту. Сукупність впливу цих та інших показників визначає рівень продуктивних можливостей тварин.

Встановлено, що рівень молочної продуктивності корів залежить від тривалості їх ембріонального розвитку та маси при народженні (табл. 2).

Дані таблиці 2 свідчать про те, що телята 3 меншою масою при народженні виростають у більш продуктивних корів, аніж середні та важкі. Так, легкі телята при народженні $(28,1$ кг) переважають середніх (30,4 кг) і важких $(33,4$ кг) за надоєм у першу лактацію на 145,2 кг та 269,7 кг, або на $3,7 \%$ та 7,1 \% відповідно. До того ж їх середня маса при народженні була меншою на 2,3 кг (8,2 \%) та 5,3 кг (18,9 \%) відповідно. Найвищу продуктивність по групі важких при народженні мали корови 3 тривалим періодом ембріогенезу, а по групах середніх і легких - із середнім. Проміжну продуктивність по всіх трьох групах мали тварини з коротким періодом ембріогенезу. У цілому вищою продуктивністю характеризувалися тварини з середньою і короткою тривалістю ембріонального розвитку. Вищезазначене краще ілюструє графік (рис. 1).

\section{2. Залежність молочної продуктивності корів від тривалості їх ембріонального розвитку} та маси при народженні

\begin{tabular}{|c|c|c|c|c|c|c|c|}
\hline \multirow{3}{*}{$\begin{array}{l}\text { Тривалість ем- } \\
\text { бріонального } \\
\text { розвитку, днів }\end{array}$} & \multicolumn{7}{|c|}{ Маса телят при народженні, кг (M $\pm \mathrm{m})$} \\
\hline & \multicolumn{2}{|c|}{ важкі (M+) } & \multicolumn{2}{|c|}{ середні $\left(\mathrm{M}_{0}\right)$} & \multicolumn{2}{|c|}{ легкі (М-) } & \multirow[b]{2}{*}{$\begin{array}{c}\text { надій у } \\
\text { середньо- } \\
\text { му, кг }\end{array}$} \\
\hline & надій, кг & $\begin{array}{c}\text { маса при } \\
\text { народжен- } \\
\text { ні, кг }\end{array}$ & надій, кг & $\begin{array}{c}\text { маса при } \\
\text { народжен- } \\
\text { ні, кг }\end{array}$ & надій, кг & $\begin{array}{c}\text { маса при } \\
\text { народжен- } \\
\text { ні, кг }\end{array}$ & \\
\hline Тривалий (M+) & $\begin{array}{c}3859,7 \pm \\
143,22 \\
\end{array}$ & 33 , & $\begin{array}{c}3785,8 \pm \\
126,41 \\
\end{array}$ & 30 , & $\begin{array}{c}3975,6 \pm \\
190,39 \\
\end{array}$ & $\pm 0,19$ & $\begin{array}{c}3870,7 \pm \\
88,50\end{array}$ \\
\hline Середній $\left(\mathrm{M}_{0}\right)$ & $\begin{array}{c}3792,8 \pm \\
162,11 \\
\end{array}$ & $34,0 \pm 0,39$ & $\begin{array}{c}4036,6 \pm \\
121,13 \\
\end{array}$ & $30,5 \pm 0,06$ & $\begin{array}{c}4185,4 \pm \\
162,39 \\
\end{array}$ & $28,0 \pm 0,29$ & $\begin{array}{c}4012,6 \pm \\
83,60\end{array}$ \\
\hline Короткий (M-) & $\begin{array}{c}3800,8 \pm \\
177,33 \\
\end{array}$ & $32,6 \pm 0,19$ & $\begin{array}{c}3929,9 \pm \\
157,45 \\
\end{array}$ & $30,4 \pm 0,08$ & $\begin{array}{c}4086,2 \pm \\
166,41 \\
\end{array}$ & $28,1 \pm 0,18$ & $\begin{array}{c}3944,2 \pm \\
95,82 \\
\end{array}$ \\
\hline $\begin{array}{c}\text { Надій у серед- } \\
\text { ньому, кг }\end{array}$ & $\begin{array}{c}3817,4 \pm \\
92,21\end{array}$ & & $\begin{array}{c}3941,9 \pm \\
78,03\end{array}$ & & $\begin{array}{c}4087,1 \pm \\
99,47\end{array}$ & & $\begin{array}{c}3950,3 \pm \\
51,47\end{array}$ \\
\hline
\end{tabular}

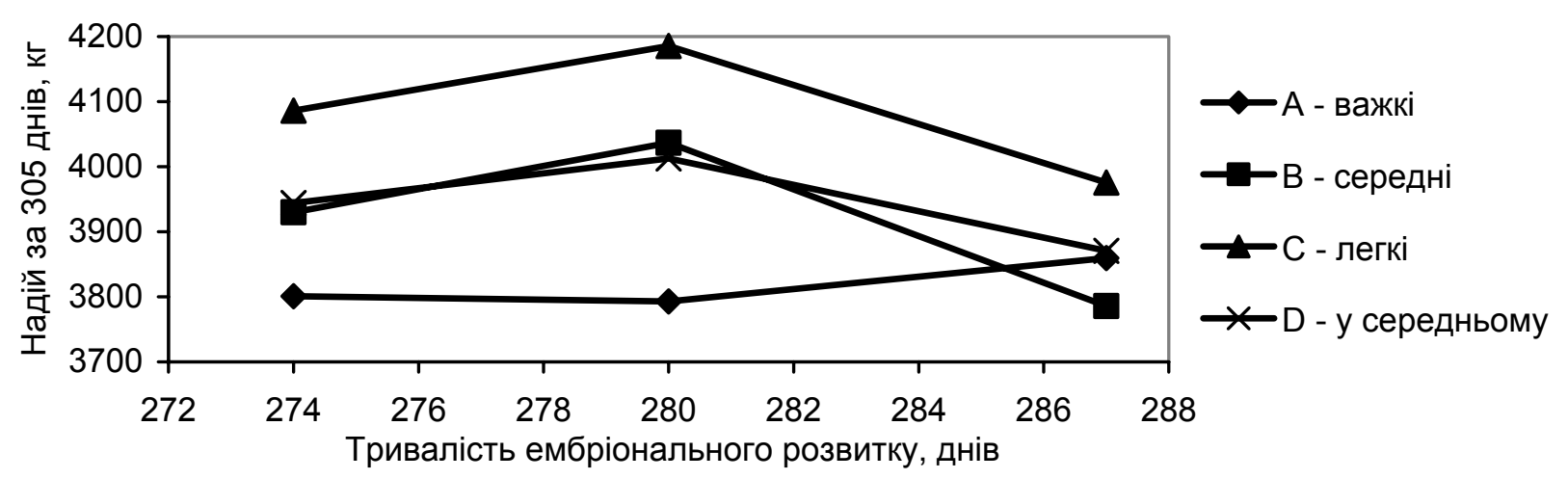

Рис. 1. Залежність молочної продуктивності корів від тривалості ӥх ембріонального розвитку та маси при народженні 
Оцінюючи новонароджене теля необхідно враховувати відношення його маси при народженні до маси матері та швидкість росту в ембріональний період, які є важливими показниками повноцінності його розвитку. Встановлено, що рівень молочної продуктивності первісток до певної міри залежить від цих показників (табл. 3).

Згідно 3 даними таблиці 3, дрібні телята при народженні мають вищу продуктивність за першу лактацію, ніж середні й великі. Різниця становить 142,9 кг і 363,9 кг, або $3,6 \%$ і 9,7\% $(\mathrm{P}>0,99)$ відповідно. Найвищою молочною продуктивністю характеризувалися дрібні телята 3 середньою швидкістю росту (рис. 2).

Цікаво, що в групі середніх телят підвищення ембріональної швидкості росту супроводжується підвищенням надоїв первісток, а в групі великих телят при підвищенні ембріональної швидкості росту відбувається зниження рівня їх продуктивності. Великі швидкоростучі телички мали най- нижчі показники надоїв із-поміж усіх груп (на 309,5 кг менше, або 92,2 \% від середнього надою по стаду).

Причиною цього, на нашу думку, є встановлене науковцями $[6,7]$ збереження енергіï ембріонального росту в постембріональний період. Iз даних таблиці 3 бачимо, що для групи великих швидкоростучих телиць характерною $є$ найвища середня маса при народженні. 3 цього можна зробити припущення, що 3 телиць даної групи виростають корови 3 підвищеним розвитком м'ясних якостей, що і $є$ причиною їх низької молочної продуктивності.

Ми вважаємо, що показники відношення маси теляти при народженні до маси матері та ембріональної швидкості росту тісніше пов'язані 3 наступним рівнем молочної продуктивності первісток, аніж їх маса при народженні й тривалість ембріонального розвитку. Завдяки використанню показників відношення маси теляти при народженні до маси матері та ембріональної

\section{3. Залежність молочної продуктивності корів від їх ембріональної ивидкості росту та співвідночення маси при народженні до маси матерів}

\begin{tabular}{|c|c|c|c|c|c|c|c|}
\hline \multirow{4}{*}{$\begin{array}{c}\text { Ембріональна } \\
\text { швидкість росту, г }\end{array}$} & \multicolumn{7}{|c|}{ Співвідношення маси телят при народженні до маси матерів, \% } \\
\hline & \multicolumn{2}{|c|}{ великі (M+) } & \multicolumn{2}{|c|}{ середні $\left(\mathrm{M}_{0}\right)$} & \multicolumn{2}{|c|}{ дрібні (М-) } & \multirow[b]{2}{*}{$\begin{array}{c}\text { надій у } \\
\text { середнь- } \\
\text { му, кг }\end{array}$} \\
\hline & надій, кг & $\begin{array}{c}\text { маса при } \\
\text { наро- } \\
\text { дженні, кг }\end{array}$ & надій, кг & $\begin{array}{c}\text { маса при } \\
\text { наро- } \\
\text { дженні, кг }\end{array}$ & надій, кг & $\begin{array}{c}\text { маса при } \\
\text { наро- } \\
\text { дженні, кг }\end{array}$ & \\
\hline & $\mathrm{M} \pm \mathrm{m}$ & $\mathrm{M} \pm \mathrm{m}$ & $\mathrm{M} \pm \mathrm{m}$ & $\mathrm{M} \pm \mathrm{m}$ & $\mathrm{M} \pm \mathrm{m}$ & $\mathrm{M} \pm \mathrm{m}$ & $\mathrm{M} \pm \mathrm{m}$ \\
\hline Швидкоростучі (M+) & $\begin{array}{c}3640,8 \\
\pm 121,57\end{array}$ & $\begin{array}{c}34,2 \\
\pm 0,31\end{array}$ & $\begin{array}{c}4112,1 \\
\pm 188,80\end{array}$ & $\begin{array}{c}32,4 \\
\pm 0,18\end{array}$ & $\begin{array}{c}3965,6 \\
\pm 184,52\end{array}$ & $\begin{array}{c}32,1 \\
\pm 0,19\end{array}$ & $\begin{array}{l}3790,8 \\
\pm 93,96\end{array}$ \\
\hline Середньоростучі $\left(\mathrm{M}_{0}\right)$ & $\begin{array}{c}3859,7 \\
\pm 153,51 \\
\end{array}$ & $\begin{array}{c}31,0 \\
\pm 0,12 \\
\end{array}$ & $\begin{array}{c}3976,8 \\
\pm 109,96 \\
\end{array}$ & $\begin{array}{c}30,4 \\
\pm 0,09 \\
\end{array}$ & $\begin{array}{c}4180,9 \\
\pm 141,36 \\
\end{array}$ & $\begin{array}{c}30,1 \\
\pm 0,10 \\
\end{array}$ & $\begin{array}{r}4008,8 \\
\pm 75,79 \\
\end{array}$ \\
\hline Повільноростучі (М-) & $\begin{array}{r}4057,0 \\
\pm 376,92 \\
\end{array}$ & $\begin{array}{c}29,3 \\
\pm 0,18\end{array}$ & $\begin{array}{c}3864,7 \\
\pm 171,95 \\
\end{array}$ & $\begin{array}{c}28,5 \\
\pm 0,14\end{array}$ & $\begin{array}{c}4084,0 \\
\pm 133,51 \\
\end{array}$ & $\begin{array}{c}27,8 \\
\pm 0,23\end{array}$ & $\begin{array}{c}4002,1 \\
\pm 102,03 \\
\end{array}$ \\
\hline $\begin{array}{c}\text { Надій у середньому, } \\
\text { кг }\end{array}$ & $\begin{array}{l}3745,5 \\
\pm 92,48\end{array}$ & & $\begin{array}{l}3966,5 \\
\pm 83,53\end{array}$ & & $\begin{array}{l}4109,4 \\
\pm 89,73\end{array}$ & & $\begin{array}{l}3950,3 \\
\pm 51,47\end{array}$ \\
\hline
\end{tabular}



Рис. 2. Залежність молочної продуктивності корів від ӥх ембріональної ивидкості росту та співвідношення маси при народженні до маси матерів 
швидкості росту вдалося розкрити певні закономірності зв'язку показників раннього ембріонального розвитку молочної худоби з рівнем ії молочної продуктивності. Застосування цих показників дає змогу визначити групи більш продуктивних первісток на початку їх постембріонального розвитку.

\section{Висновки:}

1. Молочна продуктивність корів залежить від індивідуальних особливостей їх організму, які до певної міри можуть бути оцінені при народженHi.

2. Телята 3 меншою масою при народженні виростають у більш продуктивних корів, i на-

\section{БІБЛІОГРАФІЯ}

1. Генетико-селекційні аспекти онтогенезу сільськогосподарських тварин: матеріали творчої дискусії. - К. : Аграрна наука, 2004. - 39 с.

2. Kосташ В. Б. Господарсько-біологічні особливості тварин різних ліній і генотипів української червоно-рябої молочної породи в умовах Буковини : автореф. дис. ... канд. с.-г. наук : 06.02.01 / В. Б. Косташ. - Київ-Чубинське, 2009. $22 \mathrm{c}$.

3. Маменко А. М. Взаимосвязь показателей эмбрионального развития с молочной продуктивностью первотелок / Маменко А. М., Антоненко С. Ф., Гончаров Л. В. // Зоотехния. - 2006. № 2. - C. 20-24.

4. Меркурьева E. К. Биометрия в селекции и генетике сельскохозяйственных животных. - М. : Колос, 1970. - 423 с.

5. Пабат В. О. Основи генетики і тваринництва / Пабат В. О., Вінничук Д. Т. - К. : Аграрна наука, 1997. $-184 \mathrm{c}$.

6. Подоба Е. Г. Продолжительность эмбрионального развития как показатель конституциональных особенностей животного / Подоба Е. Г. // Журнал общей биологии. - 1956. - Т. 17. - №6. C. 443-452. впаки.

3. Найбільш сприятливим для розвитку молочної продуктивності корів $є$ середній і короткий періоди їх ембріогенезу.

4. Показники відношення маси теляти при народженні до маси матері та ембріональної швидкості росту тісніше пов'язані з наступним рівнем молочної продуктивності первісток, аніж їх маса при народженні й тривалість ембріонального розвитку.

5. Використання показників раннього онтогенезу дає змогу визначити групи більш продуктивних первісток на початку їх постембріонального розвитку.

7. Подоба Е. Г. Некоторые закономерности роста молодняка крупного рогатого скота и направленное использование их с целью повышения продуктивности / Подоба Е. Г. // Журнал общей биологии. - 1958. - Т. 19. - №1. - С. 22-34.

8. Пшеничний П. Д. Спрямоване виховання молодняка сільськогосподарських тварин. - К.-Х., 1950. - $172 \mathrm{c}$.

9. Федорович С. I. Селекційно-генетичні та біологічні особливості тварин західного внутрішньопородного типу української чорно-рябої молочної породи: автореф. дис. ... докт. с.-г. наук : 06.02.01 / С. І. Федорович. - Київ-Чубинське, 2004. -38 c.

10. Чернякова Н. E. Изменчивость молочной продуктивности в связи с показателями крови и продолжительностью эмбрионального развития крупного рогатого скота: автореф. дис. ... канд. биол. наук : 03.00.15 / Н. Е. Чернякова. - К., 1975. - 25 c.

11. Legault C. R. Heritability of birth weight and its relationship with production in dairy cattle / Legault C. R., Touchberry R. W. // J. Dairy Sci. 1962. - V. 45. - P. 1226-1233. 